\title{
Comparative and serial assays of folate metabolism in anticonvulsant-treated epileptics
}

\author{
P. R. TEASDALE AND JOHN PEARCE
}

From the Department of Biochemistry and the Combined Neurological Service, Hull Royal Infirmary

SYNOPSIS A prospective study of folate metabolism has been conducted in outpatient anticonvulsant-treated epileptics on 68 occasions. An attempt was made to compare the relative sensitivities of serum and red cell measurements of folic acid, lactic dehydrogenase (LD), and 2 hydroxybutyric dehydrogenase (2HBD). The most sensitive indices of folate deficiency appeared to be serum folate, red cell LD, red cell folate, and red cell $2 \mathrm{HBD}$, respectively. The correlation between these measurements was not close, except in comparisons of red cell and serum folate. No easily performed screening test for folate deficiency emerged.

Serial changes in these measurements were carried out on 15 patients during an interval of 18 months. No progressive signs of folate depletion appeared during this time. The significance of these findings is discussed.

There is now evidence that serum folate levels are decreased in between 31 and $76 \%$ of epileptics treated with anticonvulsants (Chanarin, 1969a). The significance of this is, however, open to doubt depending upon whether or not serum folate levels are taken to be a precise index of folate deficiency. At the present time there exists some confusion as to which laboratory measurements are indicative of an absolute state of folate depletion. Assays of folate in the serum have been widely performed but the significance and relationship of such assays to red cell folate and to red cell and serum lactic dehydrogenase (LD) remain uncertain in anticonvulsant-treated epileptics.

The effects of folate depletion are potentially important as causes of $(a)$ rare cases of megaloblastic anaemia, $(b)$ various neurological syndromes which in the literature have included dementia, spinal cord lesions, visual failure, and possibly peripheral neuropathy (Brain, 1969).

Normal levels of serum LD have been reported (Reynolds, Chanarin, Milner, and Matthews, 1966) in a series of patients in a 'megaloblastic group' due to anticonvulsant therapy. Serum 2 hydroxybutyric dehydrogenase (2HBD) has been suggested as a more sensitive test than serum LD in reflecting bone marrow changes in megaloblastic anaemia (Fleming and Elliott, 1964). Reports of red cell LD in pernicious anaemia have been conflicting, Received for publication 24 April 1972. increased activity being reported by Vuopio (1963) and by Emerson, Withycome, and Wilkinson (1967), whereas no significant variations from normal have been reported by certain other workers referred to in the above papers.

We have been unable to find a consecutive series of anticonvulsant-treated epileptics in whom red cell folate levels have been investigated; nor have we been able to find reports of red cell LD values in this group of potentially folate-depleted subjects. We have therefore applied these methods to a consecutive series of outpatient epileptics on anticonvulsant therapy in an attempt to clarify these issues. We were particularly interested to assess the relative sensitivities of the various methods employed.

\section{Materials and Methods}

Estimations of red cell folate, 2 hydroxybutyric dehydrogenase (2HBD), LD, and serum folate, vitamin $B_{12}, L D, 2 H B D$, and urine Figlu were measured on 68 occasions in 26 patients (15 males aged 17 to 64 years, and 11 females aged 15 to 67 years). The patients were taking one or more of the following drugs: phenobarbitone, phenytoin, primidone, sulthiame, ethosuximide, and pheneturide for epilepsy, and were under regular surveillance at the neurological outpatient clinic of the Hull Royal Infirmary. 
The preparation of red cell haemolysates and the estimation of red cell 2 HBD and red cell LD have been described previously (Teasdale, 1972). Red cell folate levels were measured by assay with $L$. case $i$ (Hoffbrand, Newcombe, and Mallin, 1966); serum 2HBD by the method of Rosalki and Wilkinson (1960), LD by the method of Wroblewski and LaDue (1955), and folate estimations using $L$. case $i$ (Waters and Mollin, 1961). These were measured in all subjects. Serum vitamin $\mathbf{B}_{12}$ measurements were also made (Spray, 1955), normal range 170 to $970 \mathrm{ng} / \mathrm{ml}$. Urine Figlu estimations were carried out using the sensitive enzyme technique of Tabor and Wyngarden (1958) after histidine loading (Luhby and Cooperman, 1964). The normal values obtained in $\mathbf{4 0}$ healthy adults are shown in Table I. Routine haematological studies using standard methods (Dacie and Lewis, 1968) were used.

\section{Results}

\section{APPARENT PREVALENCE OF FOLATE}

DEFICIENCY

Of the 26 patients, $10(39 \%)$ had serum folate levels of less than $4 \mathrm{ng} / \mathrm{ml}$ at their initial assessment and of these patients seven had abnormal red cell folate levels of less than $166 \mathrm{ng} / \mathrm{ml}$. In addition one patient had an abnormal level of red cell folate but a borderline serum folate.
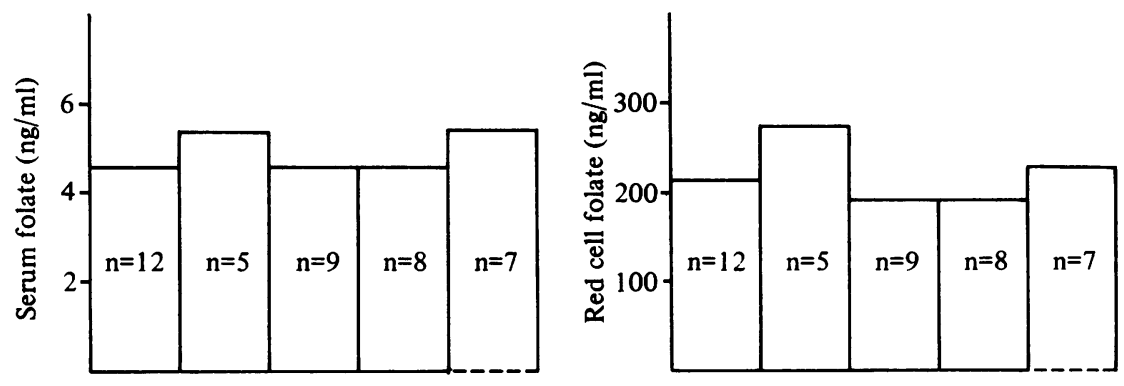

\section{SERIAL CHANGES}

In 15 patients three or more estimations were $\stackrel{\infty}{\oplus}$ carried out at three to six-month intervals during a $\overrightarrow{0}$ period of 18 months. Folate supplements were $N$ withheld from these patients and the results are shown in Figure 1. No progressing signs of deficiency are apparent.

Since red cell folate deficiency is probably the most reliable index of total body folate depletion, a

Fig. 1 Serial values in 12 patients over 18 months.
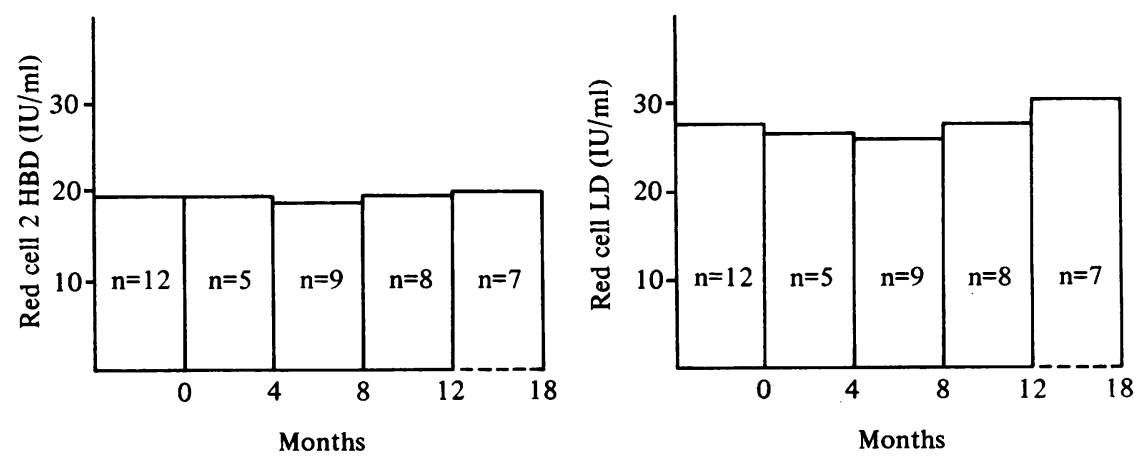
comparison with other parameters is relevant on all occasions when red cell folate is abnormally low (Table II). This shows that serum folate is subnormal in $65 \%$, but that there is little correlation with other assays which were abnormal in from 0 to $29 \%$ of comparisons.

\begin{tabular}{llr}
\hline When & RBC folate is < & $166 \mathrm{ng} / \mathrm{ml}(100 \%)$ \\
& Serum folate is abnormal in & $65 \%$ \\
Serum 2HBD is abnormal in & $29 \%$ \\
RBC 2HBD is abnormal in & $18 \%$ \\
Serum LD is abnormal in & $0 \%$ \\
RBC LD is abnormal in & $29 \%$ \\
\hline
\end{tabular}

Table II Percentage of abnormal results in different measurements when red cell folate is subnormal

In those four patients with initial low serum folate levels and normal red cell folate, there is a possibility that low serum folate could be a false positive result. Follow up for 18 months, however, shows persistent low serum folate in all four subjects. Red cell folate has remained normal in three of the patients but in the fourth the level has gradually fallen to subnormal levels. These results merit close scrutiny and are detailed in Table III. Red cell LD has been raised in three of these four subjects, but with some variation. Two patients with low normal serum

\begin{tabular}{|c|c|c|c|c|c|c|}
\hline & $\begin{array}{l}\text { Serum } \\
\text { Folate }\end{array}$ & $\begin{array}{l}\text { RBC } \\
\text { Folate }\end{array}$ & $\begin{array}{l}R B C \\
2 H B D\end{array}$ & $\begin{array}{l}\text { Serum } \\
2 H B D\end{array}$ & $\begin{array}{l}R B C \\
L D\end{array}$ & $\begin{array}{l}\text { Serum } \\
L D\end{array}$ \\
\hline $\begin{array}{r}1 \\
\mathrm{a} \\
\mathrm{b}\end{array}$ & $\begin{array}{l}3 \cdot 4 \\
3 \cdot 8\end{array}$ & $\begin{array}{l}214 \\
240\end{array}$ & $\begin{array}{l}18 \cdot 5 \\
22 \cdot 2\end{array}$ & $\begin{array}{l}200 \\
230\end{array}$ & $\begin{array}{l}23 \cdot 2 \\
26 \cdot 2\end{array}$ & $\begin{array}{l}330 \\
350\end{array}$ \\
\hline $\begin{array}{c}2 \text { a } \\
\text { b } \\
c \\
\text { d } \\
\text { c }\end{array}$ & $\begin{array}{l}3 \cdot 2 \\
3.4 \\
3 \cdot 8 \\
3.6 \\
3.4\end{array}$ & $\begin{array}{l}269 \\
210 \\
224 \\
178 \\
185\end{array}$ & $\begin{array}{l}23 \cdot 4 \\
\overline{19 \cdot 3} \\
19 \cdot 7 \\
18 \cdot 5\end{array}$ & $\begin{array}{l}200 \\
150 \\
250 \\
230 \\
200\end{array}$ & $\begin{array}{l}29 \cdot 2 \\
27 \cdot 2 \\
22 \cdot 5 \\
24 \cdot 0 \\
22 \cdot 8\end{array}$ & $\begin{array}{l}320 \\
330 \\
280 \\
280 \\
300\end{array}$ \\
\hline $\begin{array}{r}3 \text { a } \\
\text { b } \\
\text { c }\end{array}$ & $\begin{array}{l}1 \cdot 6 \\
3 \cdot 4 \\
3 \cdot 8\end{array}$ & $\begin{array}{l}248 \\
256 \\
276\end{array}$ & $\begin{array}{l}21 \cdot 7 \\
21 \cdot 1 \\
18 \cdot 7\end{array}$ & $\begin{array}{l}250 \\
120 \\
150\end{array}$ & $\begin{array}{l}28.6 \\
28.0 \\
26.8\end{array}$ & $\begin{array}{l}470 \\
270 \\
200\end{array}$ \\
\hline $\begin{array}{r}4 a \\
b \\
c\end{array}$ & $\begin{array}{l}2.0 \\
3.0 \\
3.8\end{array}$ & $\begin{array}{l}170 \\
154 \\
168\end{array}$ & $\begin{array}{l}18 \cdot 1 \\
15.9 \\
14.9\end{array}$ & $\begin{array}{l}280 \\
280 \\
270\end{array}$ & $\begin{array}{l}24 \cdot 4 \\
20 \cdot 7 \\
18 \cdot 5\end{array}$ & $\begin{array}{l}400 \\
400 \\
400\end{array}$ \\
\hline
\end{tabular}

Table III Serial assays in four patients over 18 months

and red cell folate levels were given folic acid $5 \mathrm{mg}$ tds for six to 12 months. After this was withdrawn, the levels fell to subnormal values in 14 to 24 months. (Fig. 2).

Fig. 2 Fall of red cell and serum folate after withdrawal of folic acid supplements, patients on anticonvulsants throughout. 
SERUM B $B_{12}$ RESULTS

With the exception of one result all the measurements were within the normal range. The values obtained ranged from 165 to $890 \mathrm{pg} / \mathrm{ml}$ with a mean of $467 \mathrm{pg} / \mathrm{ml}$.

FIGLU AFTER HISTIDINE LOADING

With one exception all the determinations were within the normal range. The values obtained ranged from 1.0 to $36.8 \mathrm{mg} / 24 \mathrm{hr}$, with a mean of $8.0 \mathrm{mg} / 24$ hr.

ROUTINE HAEMATOLOGICAL TESTS Normal results were obtained in respect of $\mathrm{Hb}, \mathrm{WBC}$ count, and PCV.

Blood films were examined by a haematologist without knowledge of the other results, and macrocytosis was reported in $14 \%$ of the 68 specimens.

\section{Discussion}

In view of the neurological complications of folate deficiency reported in the literature, estimates of this abnormality have clinical relevance. Until now the main difficulty has been in defining in absolute terms the limits of deficiency of folate. The present results and previous papers (Chanarin, 1969b) indicate that a low level of red cell folate is evidence of true folate deficiency, and that a low serum folate suggests a negative folate balance which in time may lead to true deficiency.

The number of low serum folate results $(39 \%)$ was similar to previous reports (31 to $76 \%$ ) (Chanarin, 1969a). To the best of our knowledge no data exist for serial red cell folate levels in epileptics receiving anticonvulsant drugs. Of particular significance is the fact that some patients exist for up to 15 months with levels well below the normal range without showing any haematological change. According to Herbert (1962), after 19 weeks of experimentally induced folic acid deficiency, abnormal Figlu excretion was noted, followed by macrocytosis, a megaloblastic bone marrow, and anaemia. This isolated experiment contrasts with the present observations which indicate that in the anticonvulsant-treated epileptic, folate deficiency can be tolerated for a long time without ensuing haematological abnormality.

A low serum folate level in our experience is not necessarily succeeded by lowered red cell folate, low values having been obtained for up to 20 months with consistent normal red cell folate levels. Despite this, in two patients who were given folate supplements and then who had red cell folate levels in excess of $1000 \mathrm{ng} / 100 \mathrm{ml}$ the red cell levels fell to below the normal range in 10 to 12 months after the folic acid was withdrawn (Fig. 2). This suggests that red cell folate stores may be quickly depleted by continuous anticonvulsant medication. It appears that in this group of patients a negative folate balance may develop quickly, yet the red cell synthesis of haemoglobin remains stable and unimpaired for many years and probably indefinitely. Depletion of folate during phenytoin therapy has been attributed at least in part to reduced absorption of food folate polyglutamates.

The results of the present investigation indicate that in anticonvulsant-treated epileptics folate deficiency is disclosed most frequently by laboratory assays of serum folate, red cell $\mathrm{LD}$, red cell folate, and red cell $2 \mathrm{HBD}$. The highest percentage of abnormal results was reflected in measurements of serum folate and red cell LD. These measurements are not closely correlated.

The 2HBD and LD enzyme measurements in the red cell produced 21 and $38 \%$ of abnormal results respectively. Increased levels of red cell LD in megaloblastic anaemia and other haematological conditions have been reviewed by Vuopio (1963), and although this measurement is not specific it might prove to be of value in assessing the folate deficit of epileptics receiving anticonvulsant drugs, though its sensitivity appears comparable to serum and red cell folate estimations.

Laboratory measurements of serum $2 \mathrm{HBD}$ and serum LD are more easily and quickly performed than the other methods, but the present findings indicate that abnormal results are found so infrequently in early folate deficiency that these methods are unsuitable for the detection of this state in anticonvulsant-treated patients. This corresponds to the results in folate deficiency states of different aetiology.

Similar arguments apply to the routine assay of urine Figlu excretion after histidine loading, although this measurement may be valuable in folate depletion of different causation. The incidence of abnormal Figlu results reported in the literature regarding folate deficiency in epileptics is variable, and this may be due to techniques being used which lack sensitivity, or be related to nutritional defects in addition to the action of anticonvulsants. The technique used here was chosen because of its sensitivity yet only one result was slightly outside the normal range.

It is evident that epileptics with folate deficiency can continue for years without any sign of megaloblastic anaemia. Despite the controversy in the literature, we have no clinical evidence to justify the routine administration of folate in such patients, and there is nothing to suggest that this state has any effect on fit frequency or mental function 
(Grant and Stores, 1970). In view of this and the conspicuous lack of evidence that abnormal results of assays of folate metabolism predict haematological changes, it is doubtful whether determinations of serum or red cell folate and enzyme levels are necessary in the routine investigations of anticonvulsant-treated epileptics. No quickly and easily performed screening test for folate deficiency emerges from the present study. It is suggested that comprehensive studies are indicated not as a routine but in the clinical context of haematological or neurological symptoms arising in this group of patients.

We are indebted to Dr L. S. Sacker for examination of the blood films. Routine haematological tests were performed by the Haematology Department, Kingston General Hospital.

\section{References}

Brain, M. C. (1969). In Recent Advances in Neurology and Neuropsychiatry, 8th ed., edited by $M$. Brain and $M$. Wilkinson, pp. 129-133. Churchill, London.

Chanarin, I. (1969a and b). In The Megaloblastic Anaemias, (a) p. 839, (b) p. 326. Blackwell, Oxford and Edinburgh.
Dacie, J. V., and Lewis, S. M. (1968). In Practical Haematology, 4th ed., ch. 2 and 3. Churchill, London.

Emerson, P. M., Withycome, W. A., and Wilkinson, J. H. (1967). The origin of the elevated serum lactate dehydrogenase in megaloblastic anaemia. Brit. J. Haemat., 13, 656-664.

Fleming, A. F., and Elliott, B. A. (1964). Serum enzyme tests in megaloblastic erythropoieses in anaemia of pregnancy. Brit. med.J., 2, 1108-1111.

Grant, R. H. E., and Stores, O. P. R. (1970). Folic acid in folatedeficient patients with epilepsy. Brit. med. J., 4, 644-648.

Herbert, V. (1962). Experimental nutritional folate deficiency in man. Trans. Ass. Amer. Phycns, 75, 307-320.

Hoff brand, A. V., Newcombe, B. F. A., and Mollin, D. L. (1966). Method of assay of red cell folate activity and the value of the assay as a test for folate deficiency. J. clin. Path., 19, 17-28.

Luhby, A. L., and Cooperman, J. M. (1964). Folic acid deficiency in man and its interrelationship with vitamin $B_{12}$ metabolism. In Advanc. metab. Dis., 1, 263-334.

Reynolds, E. H., Chanarin, I., Milner, G., and Matthews, D. M. (1966) Anticonvulsant therapy folic acid and vitamin B12 metabolism and mental symptoms. Epilepsia, 7, 261-270.

Rosalki, S. B., and Wilkinson, J. H. (1960). Reduction of ketobutyrate by human serum. Nature (Lond.), 188, 1110-1111.

Spray, G. H. (1955). An improved method for the rapid estimation of vitamin B1 2 in serum. Clin. Sci., 14, 661-667.

Tabor, H., and Wyngarden, L. (1958). A method for the determination of formiminoglutamic acid in urine. J. clin. Invest., 37, 824-828.

Teasdale, P. R. (1972). In the press.

Vuopio, P. (1963). Red cell enzymes in anaemia. Scand. J. clin. Lab. Invest., 15, Suppl. 72, 14-22.

Waters, A. H., and Mollin, D. L. (1961). Studies on the folic acid activity of human serum. J. clin. Path., 14, 335-344.

Wroblewski, F., and LaDue, J. S., (1955). Lactic dehydrogenase activity in blood. Proc. Soc. exp. Biol. (N.Y.), 90, 210-213. 